\section{Why Co-operatives?}

Subrata Mukherjee and Manoranjan Das

\section{ABSTRACT}

In 2006, Muhammed Yunus and the Grameen Bank received the Nobel Peace Prize for their efforts through micro-credit to create economic and social development. Muhammed Yunus received the prize not in the field of economics because only sustainable development of the proletariat and the marginalised sections of society can bring peace. More than $80 \%$ of the world's population lives in countries where income differentials are widening. The poorest $40 \%$ of the world's population accounts for $5 \%$ of global income, while the richest $20 \%$ accounts for three quarters of world income. According to the World Bank (WB), the proportion of people in the developing world living on less than $\$ 1.25$ a day was $20.5 \%$ in 2010, down from $43.1 \%$ in 1990 and $52.2 \%$ in 1981 (in 2005 prices). That is 1.22 billion people lived on less than $\$ 1.25$ a day in 2010 compared with 0.91 billion in 1990 and 1.94 billion in 1981. In this paper an attempt is made to explain the relevance of Marxism and the need for the co-operative movement to assist in providing a means for social well-being of the downtrodden classes of people.

Keywords: Economy and social development, sustainable development, Marxism

\section{Introduction}

Both Marxism and the Cooperative Movement can be described as means for the socio-economic development of the downtrodden and marginalized sections of society. Both Marxism and Cooperative Movement started in Europe and have since gained firm footing it firm footing in other countries as well. Marxism aimed for a classless society resulting from the struggle between the two great classes directly facing each other - bourgeoisie and proletariat with the internationalization of all societies.

The Industrial Revolution which started around 1760s changed not only the mode of production but also brought about a metamorphosis in societal philosophy and structure and led to the formation of two classes, namely the bourgeoisie and the proletariat proletariat - who were the oppressor and the oppressed. Karl Marx, through the international Communist movement, fought against the ills of the Industrial Revolution to gain better working conditions and improved standard of living for the proletariat. Marx conceived of the idea of the cooperative as a function of the capitalist mode of

\begin{tabular}{|l|c|}
\hline Chile & 1925 \\
\hline New Zealand & 1934 \\
\hline Brazil & 1945 \\
\hline China & 1979 \\
\hline
\end{tabular}

Table 1: Year of Establishment of Central Banks for Various Countries; source: Author's Compilation

One of most important issues is gradually to abolish the distinction between town and country by a more equitable distribution of the population throughout the country. Ex-President of India Sri A. P. J. Kalam professed on the concept of PURA in his Vision 2020, i.e. Providing Urban facilities to the Rural Area. Without the development of infrastructure, the development of the economy is not possible. Marx advocated the centralization of the means of communication and transport in the hands of the state. This argument has gained importance in India in the past decade through the formation of a National Commission on Infrastructure such as roads and telecommunications. Various schemes like Golden Quadrilateral and Pradhan Mantri Gram Sadak Yojana were started during the regime of Sri Atal Bihari Vajpayee as the Prime Minister. The Formation of the National Highway Authority of India (NHAI) and Telecom Regulatory Authority of India (TRAI) were a move in

\begin{tabular}{|l|l|}
\hline Country & $\begin{array}{l}\text { Telecommunications Regulatory } \\
\text { Authority }\end{array}$ \\
\hline Australia & $\begin{array}{l}\text { Australian Communications and Media } \\
\text { Authority }\end{array}$ \\
\hline Canada & $\begin{array}{l}\text { Canadian Radio, Television and } \\
\text { Telecommunications Commission }\end{array}$ \\
\hline Denmark & $\begin{array}{l}\text { National IT and Telecommunications } \\
\text { Agency }\end{array}$ \\
\hline USA & Federal Communications Commission \\
\hline UK & Office of Communications (OFCOM) \\
\hline
\end{tabular}

Table 2: Telecommunications Regulatory Authorities for Various Countries; source: Author's Compilation

The issue of corporate governance is gaining importance and it is becoming mandatory for reporting on corporate governance to be provided in the annual reports of stock exchange-listed corporations. The Green Revolution has enabled the country to become self-dependent in terms of the consumption of agricultural products. The effort to bring wasteland into cultivation or development of land for economic purposes can help develop economically backward areas. The problems of insurgence is mainly in the economically backward areas and, there, the fight between the bourgeoisie and proletariat - here the insurgent people, marginalized people and neglected people - stil continues more than 150 years after the publication of the Communist Manifesto. The concept of free education for all children in public schools provides a ladder for the economic and social developmen of society. The Integrated Child Developmen Schemes (ICDS) and midday meals provide incentives for children who might otherwise drop out to remain in school and pursue their studies.

In the vision of Marx, in place of the old bourgeoisie society, with its classes and class antagonisms, we shall have an association in which the free development of each is the condition for the free development of all. This can be termed as a form of utopian thought, as also are the following elements of the Manifesto such as the abolition of land as property, the application of all rents from land to public purposes, the abolition of all right of inheritance, confiscation of the property of all emigrants and rebels and the equal obligation of al to work.

Beginning with the last point of equal obligation of all to work, it is natural that all people canno do equal work, which is not only due to physical, mental and emotional competence to work but, also, because the urge to work demands incentives and motivation. Even unskilled work demands motivation and the theory of Herzberg on motivation describes job context and job content In Chapter II of the Communist Manifesto, Marx advocates that the working class belongs to no country. This means that the mobility of worker and wage earners is not restricted but it contradicts the statement on confiscation of the property of al emigrants and rebels. In a family, one should no expect to have the consensus of all members on every issue and so a similar situation for an entire class can scarcely be expected. The voice of the opposition cannot be choked forever, even if it can be suppressed for a period of time. Even animals try to shelter their offspring. Regarding the abolition of land as property and the abolition of all rights of inheritance, this can only really be advocate by those who have nothing at their disposal. It 
is against the law of nature. The state cannot control emotions or take away the natural love their offspring. It is not chimerical to suppose that people will eventually accept equality, when all are educated, polite and clear, very simple comforts will suffice for each; the desire for a superior position is largely due to a dislike of association with rude, ignorant or dirty persons. Every human behaviour of different human beings plays the same roles or characters in similar situations which even contradicts or violates previous character or forms of behaviour and thought which can be termed as Role Conflict. Had Marx considered role conflicts in human behaviour, then the above proposition could not have been included in the Manifesto.

State Management is neither always prompt nor always ideally efficient; the state servant who has nothing to gain or lose is rightly precluded from running risks, he tends to fall into set habits, he cannot easily free himself from unsatisfactory subordinates. In other words, state management is not always economical, and the waste which has been expelled return by a new door. Nor in reality which all are government servant; each man's pay depends on the state and he unites with his fellows to safeguard his interests. Now wages are always paid from profits; the state is the capitalist and must maintain its fixed capital and save something for new works; there is a limit to economics in managenth, there is a linit to econics in by raising prices, and there will be an inglorious struggle in the political arena between the various industries, each striving to push up the price of its own products in order to obtain high wages, while holding down the wages of other industries in order to buy their products cheaply It is not conceivable that the average labourer in his industrial or his electoral capacity should be assured of receiving justice.

3. Co-operative Movement in Thailand

Cooperation aims at protecting the weak and poor from the strong and rich. It is the panacea for all economic and social evils. Only that form of organisation which is based and operated upon the principles of democracy, liberty, fraternity, social and economic justice can deliver the goods.

Cooperation is also a philosophy, a religion and way of life. "The idea of cooperation is something larger than merely an efficient and economic way of doing things, It is economics, it is fair, it equalise and prevents disparities. But it is something even deeper than that: it is really a way of life." Hence the success of cooperation is essential for improvement of life. Democratic management is one of the mos important principles of cooperation. "It is a system of social organisation based on the principles of unity, economy, democracy, equity and liberty." It is neutral to political, religious and linguistic variances.

Cooperation is a golden mean between the two extremes of Capitalism and Socialism. Capitalism is an economic system based on private ownership and control of means of production and distribution with minimum of government control. This system provides an incentive for individual initiative an hard work. But this system invariably results in monopoly, exploitation and inequality in income and opportunity.

Socialism, on the other hand, is based on complete ownership and control by the government. While socialism eliminates the evils of capitalism, it does not recognise private ownership and individual freedom. Cooperation brings socialism without sacrificing individuality. There is no coercion or violence in cooperation.

There is a misconception that cooperatives require little management as they are not motivated by profit. It was believed that the great virtues of the cooperative principles themselves will contribute on their own to the success of cooperatives. The behaviour of all people concerned with the cooperatives viz., members, employees, executives and users are assumed to be ideal. But the reality is different. So, the need for management is more for cooperative organisations than others since cooperatives have to achieve operational efficiency without sacrificing the principles of cooperation.

The universally-accepted definition of a cooperative as embodied in the Statement of cooperative Identity [1995] is as follows: "A cooperative is an autonomous association of persons united voluntarily to meet economic, social and cultural needs and aspirations through a jointly- owned and democratically-controlled enterprise." The definition lays a special emphasis on the social and economic objectives of a cooperative. And the definition is based on certain cooperative and ethical values.

Agricultural cooperatives in Thailand have undertaken a bold step in promoting an integrated initiative under the banner 'One Village One Product' [OTOP]. The agricultural cooperatives provide guidance and technical support to their women members to undertake economic activities to enhance to improve their social and economic status.

\section{What is 'One Village One Product'?}

"One-Village-One Product" [in Thailand it is called 'One Tambun One Product-OTOP] [Tambun means a village in Thai language] concept of Japan is worth a mention. The concept, after its successful implementation in Japan, has been adopted by various countries in the Region with appropriate modifications e.g., China, Indonesia, Malaysia, Philippines, Thailand and the United States. The guiding principles of the Movement are: [i] Going local yet global; [ii] Independence and Creativity; and [iii] 'One Village-One Product' movement as a human resources development activity.

One Tambun One Product [OTOP] is a local entrepreneurship stimulus program designed by Thailand's former Prime Minister Thaksin Shinawatra during his 2001-2006 Thai Rak Thai government. The program aimed to support the locally-made and marketed products of each Thai Tambun [sub-district]. Drawing its inspiration from Japan's successful "One Village One Product" [OVOP] program, the OTOP program encourages village communities to improve the local products' quality and marketing, selecting one superior product from each Tambun to receive formal branding as its "starred OTOP product". It provides both a local and national stage to promote these products. OTOP products include a large array of local products, including traditional handicrafts, cotton and silk garments, pottery, fashion accessories, household items and food.

Logic of the Concept: The logic is straightforward: The main aim is rural development and job creation through financial, technical and marketing assistance; Encourage specialisation and brand development by partnering community skills with modern business practices; Use new technology and the Internet to link small producers with consumersEconomic development from the community level upward

Business Development: Under the concept, community groups are encouraged to devise their own product ideas for development into busines plans with due consideration to the following factors:

Financial support can come from state development banks, private venture capital, or government's own rural development projects, or from cooperatives and their federations and banks;

Duplication in products is inevitable - there can be as many products as there are villages;

In marketing facilitation government support is crucial;

Products sampling: Varieties of fruits and vegetables; handicrafts, clothing, farm products, pickles, fish, ornamental plants;

Focus on all local consumers. Markets abroad, Linkages with tourist industry and bulk users/ consumers;

Reacting buyers will depend on heavy state support to promote goods, given the limited resources available for community groups and start-up enterprises to spend on marketing and advertising;

Caution: Encourage countries to shift their resources away from low-selling products to those offering more promising opportunities, and

An area known for producing high quality lime, for instance, might first look to develop foo stuffs taking advantage of the local produce. But if good failed to sell, the community might consider shifting to leatherwear or woven baskets to tap consumer demand.

What is important under the programme [concept] is having communities learning about joining and cooperating together about fostering an entrepreneurial spirit among people who wish to better their income potential. While some might fail, others could develop into full-blown small and medium-size enterprises. 
Drawbacks: Of course, there are some drawbacks in the concept, but these can be overcome by finding a collective solution:

Focus is too much on the supply side with insufficient thought on demand; Fear of needless duplication; Differences between individual villages; Low production; Erratic supply; Lack of standardization; The question of acceptability; Problems of marketing; Low level of financial supply and high rate of interest; Financing institutions fear unless guaranteed by the state; Will the consumers be able to buy everything that is offered; In the beginning there will be a flood of products but how many can sustain themselves on various grounds e.g. quality, acceptability, pricing, continuity of supply etc.

The significant factor is the positive role that cooperatives can play to enhance the capacities and capabilities of their members. Cooperatives can offer credit, logistic support, and a market place. Times are changing in the business world, and if the cooperatives do not move with the time they are surely going to lose ground and the participation of their members

Linkages with Agricultural Cooperatives in Thailand

\section{Case Study of two co-operative is given below:}

Ban Paeo Agricultural Cooperative Limited, Ban Paeo, Samutsakorn. The cooperative was formally established in 1974 with 621 members with a share capital of Thai Baht 130,000. The cooperative is located in the neighbourhood of Bangkok. Farmermembers in the area grow coconut, especially young coconut to meet the needs of the people B Bankok. The mar The through middlemen. Initially there were 12 small groups which were doing the business on their own, but the Cooperative Promotion Department [CPD] of the government grouped them into a cooperative to do the business on a collective basis. At present [2013] there are 3,496 household members out of which there are 1,248 women members. Though the area is fit for cultivating paddy, but the current preferred products are: coconut, banana, star fruit, red apple, guava, vegetables and fisheries.

Principle business lines of the cooperative are: farm credit [short and medium term]; Purchasing and supplies [fertilizer and farm chemicals including saplings]; savings [short term deposits and fixed deposits], drinking water [processing and bottling and istribution to nearby factories, tourists, households in the area including to some areas in Bangkok], etc.

While the membership remained almost static [3496 households] over three years [2011-2013], there has been a marked improvement in members' share [TB $56 \mathrm{~m}$ in 2011, TB $57 \mathrm{~m}$ in 2012 and TB 59m in 2013 . Business turnover also remained constant, but the profits earned by the cooperatives are tax-free [as is the case with all cooperatives in Thailand]

The cooperative employs 22 fulltime personnel. Elections are held every 2 years. The cooperative sources loan from the Bank for Agriculture and Agricultural Cooperatives-BAAC [a government financial institution]

Some of the facilities of the cooperative are: Own office building with proper infrastructure, gas station, water treatment plant, cold store, warehouse and transport vehicles.

Role of Supporting Agencies: The Cooperative Promotion Department [CPD] is the prime-mover in strengthening the cooperative and its activities. Some of the services of the CPD are: Management support, advice, training and education, linkage with government private enterprises, financia assistance by way of easy loans and grants Identifying women members who are willing to undertake business activities under OTOP or under any other programme.

Cooperative Audit Department [CAD]: Timely conduct of yearly audit, monthly/half yearly regular inspection and guidance visits;

Cooperative League of Thailand [CLT]: Board/Staff training, cooperative member education programme distribution of information material, sponsoring participants to national and international meetings arranging visits of foreigners to cooperatives etc. Support to women members to undertake OTOP activities.

Problem Areas: Some of the problem areas of the cooperative are: Disbursement of Credit an management of defaults [almost $76 \%$ ]. No loans are given to the defaulters, which means some members get disappointed with the services of the cooperative.
Baan Kaset Pattana Coop Group, 64/1 M4 T. Kaset Pattana, Baan Paeo, Samutasakorn. The group has been promoted by the Baan Paeo agricu cooperatives a member of the cooperative. The group was established in 1997 with 50 members with the support of the CPD. The initial share capital was TB 40,000 [TB 30,000 was contributed by the $\mathrm{CPD}$ ] with every member holding two shares of $\mathrm{TB}$ 100 each. The current share capital is TB 500,000 .

The area is known for the cultivation of aloe vera. There was a factory which used to procure the herb from the farmers and process it. When the factory closed down, the farmers lost interest and through the motivation and guidance provided by the Agricultural Cooperative and the CPD, the farmers gathered together to process the herb all by themselves. Ms Somsri provided the much needed support and guidance and formed a group of women to organise a processing facility.

The group started gathering the herb from the members and process it in a scientific manner and of products for distribution. Some of the major products of the group are: aloe vera juices, and a range of health drinks including concentrates. It also undertook collection and production of artificial flowers, and Okra red flower. Major consumers of the products are local hospitals, community of the area and for exports. The marketing is done through a business agency which is exporting the products to various ASEAN countries [especially Cambodia and Laos]

Another major business activity is credit - it serves as a bank to the local community. Purchasing business includes: raw material, sugar, bottles, labels etc.

While the membership remained constant over the last three years, the members share increased to TB 50,000 in 1013 from TB 10,000 in 2011. The turnover in 2013 was TB $4 \mathrm{~m}$. Profits earned are tax-exempted, as is the case with all women group business activities in Thailand.

Members of the group are paid TB 220 per day for their work.

Role of Supporting Agencies: Several agencies provide support to local initiatives.
CPD and Kasetsarat University [Agriculture University]- provides technical guidance and financial support;

Agricultural Cooperative: Guidance, market place and linkages

CLT supports the group through the agricultura cooperatives and provides education an training support;

Problem Areas: Some of the problems of the group are: Marketing of juices; expansion of business; Maintaining the quality of products [it has to be monitored constantly not only by the group but by government health and food departments].

Agricultural cooperatives, farmers' groups an vocational groups in Thailand play an important role in community development. They produce a wide variety of quality products from local resources fo sale. Their activities help reduce unemployment, generate community income and add more value to community resources. The products include organic farm products, processed food, textile, handicraft, herbal products etc. they are made of local resources with high quality process and unique designs. Some of them are modern while many of them are unique with traditional Thai style.

There were 7,837 cooperatives of all types in the country out of which there were 4,361 [56\%] agricultural cooperatives in January 2011. The Cooperative Movement is represented by the Cooperative League of Thailand [CLT] which has the status of a national apex. The Ministry of Agriculture and Cooperatives of the Royal Thai Government is responsible for the development of agriculture and promotion of cooperatives. The two departments of the Ministry i.e., the Cooperative Promotion Department [CPD] and the Cooperative Auditing Department $[\mathrm{CAD}]$ are intimately connected with the regulation and promotion of cooperative institutions. All cooperatives are registered by the Registrar of Cooperative Societie placed within the framework of the Ministry. The Cooperative League of Thailand [CLT] works in close collaboration with the Ministry on al cooperatives-related issues.

The Ministry and the CLT are working closely on the promotion and strengthening of vocational groups, generally within the framework of the 
national programme 'One Village One ProductOTOP'.

Some of the initiatives taken by the vocational groups have earned national recognition and were able to strengthen social cohesion and financial conditions of the members. Agricultural Cooperatives and women's groups have been able to establish successful working relations due to the technical and financial support of the government as well as of the CLT.

A sample of the products of vocational groups is given below:

i. Clay flowers - Orchids on timber. Best for gifts, souvenirs and decorations. Clay Flower Production Group, Bangkok;

ii. Bamboo Baskets and Slippers. Bamboo Basket, Bannoenphai Basketry Group, Bangkok;

iii. Cowboy Hats and other fancy Items. Tambon Khok Tum-Khok Dang Housewives' Group, Saraburi;

iv. Ceramic Household and Gift items. Phasomsap Ceramic Group, Nakhon Pathom,

v. Products of Coconut Shells for household and temple decorations. Coconut Shell Handicraft Group, Samut Sakhon;

vi. Quality Rice of Nakhon Phanom. That Phanom Agricultural Cooperative Limited. Nakhon Phanom.

vii. Shawls. Samakki Bansa Ngo Weaving Group, Bueng Kan;

viii. Organic Rice Bran and Germ Oil. Bak Ruea Farmer Group, Yasothon;

ix. Stone and Silver Necklace products. Ban Chem Niang Group, Surin;

x. Silk Scarves. Weaving Group of Wiang Chai Agricultural Cooperative, Chian Rai;

xi. Processed and fresh fruits [Persimmon/Peach]. Fresh Fruit Royal Group, Chiang Mai;

xii. Umong Wine made from quality fruits. Umong Wine Cooperative Limited, Lamphun;

xiii. Shrimp Paste. Banthungyipheng Ruamjai Cooperative Women's group, Krabi;

xiv. Durian Chips, Baked Sweet Banana, Agricultural

\section{Products Processing Group, Chumphan}

xv. Glass Paintings. Glass Painting group under PaKlok's Farmers' Group, Phuket;

xvi. Fruit Wines. Chai Buri Agricultural Cooperative, Surat Thani.

The outstanding experiences of vocational group and strong developing working relations with agricultural cooperatives have many lessons which can contribute to the success of the initiative of ASEAN Economic Community [AEC]-2015 which are based on "One Vision, One Identity and One Community". The Cooperative Movement of Thailand has many reasons to qualify to play an active role in the achievement of the mission of the Community.

\section{Conclusion}

Marx advocated about the Unity of the proletaria to fight against the bourgeoisie, the fight between the oppressor and the oppressed. He advocated that the proletariat have to dominate the political power to fight the bourgeoisie. Whereas the Cooperative Movement advocates for mutual trus and faith among the members of the cooperative. The Cooperative Movement emphasizes on the socio-economic growth of the downtrodden an marginalized sections of the society and gains its social status through economic upliftment. Mc Younis have proved it in Bangladesh through his Gramin Bank how the poor and marginalized women of the society can help in the economic development. Marx admitted that the bourgeoisie itself, supplies the proletariat with its own elemen of political and general education; in other words it furnishes the proletariat with weapon for fighting the bourgeoisie. Change is the law of nature, Marx had not considered about the change of proletariat into bourgeoisie.

As Lenin admitted that world is not ready to work without individual gain, the cooperation may claim to offer a means of removing the evils of capitalism without exciting the passions of the syndicalist or accepting the clumsy yoke of the state. Lenin's Cooperative plan was based on Kar Marx and F. Engels theoretical propositions on the importance of socializing small scale production during the transition from Capitalism to Socialism. Lenin advocated that the cooperatives can only be auxiliary forces of the workers army fighting for political power. But once the workers have secured that power then the role of the cooperative can be and must be enormous when assisted by the workers' state. Then and then only can it lay the foundations of the Cooperative Commonwealth and expand to its fullest capacity. During his New Economic Policy in 1923, he went so far as to equate cooperation with socialism, not only as a transitional stage to socialism but saying that cooperation is socialism. Lenin argued that cooperatives play an important educational role in developing class consciousness

\section{References}

Governance and Social Development Research Centre(2011). Help Desk Research, Cooperatives and Development.

Howarth, M (2007). Worker co-operatives and the phenomenon of empress as recuperates in Argentina. Manchester: Co-operative College

Iliopoulos C \& Cook ML (1999). The internal organization of the cooperative firm: An extension of a new institutional digest. Journal of Cooperatives $14: 77-85$

International Co-operative Alliance (2013). Co-operative Identity, values \& principles or developing civilized cooperators. Lenin goes on to conclude that the "system of civilized cooperators is the system of socialism".

If we combine the policies of Marx like progressive or graduated income tax, centralization of credit in the hands of the state, abolishing the distinction between town and country, developing the infrastructure, development of the waste lands and compulsory education for all children along with the cooperative movement an alternative economic method can be developed.

International Labour Organization (ILO) (2001). Repo V (1) Promotion of Cooperatives, International Labour Office, Geneva.

Merrett, C and Walzer, N (eds, 2001). A Cooperative Approach to Local Economic Development, Quorum Books. Retrieved from http://ica.coop en/what-co-op/co-operative-identity-valuesprinciples

Sexton, RJ (1986). The formation of cooperatives: A game-theoretic approach with implication for cooperative finance, decision making, and stability. 